\section{A comparison of epidural tramadol and epidural morphine for postoperative analgesia}

The present study compared epidural tramadol with epidural morphine for postoperative analgesia in 20 patients undergoing major abdominal surgery. Intraoperatively, the patients were anaesthetized by a balanced technique of general anaesthesia combined with lumbar epidural lidocaine. In ten of the patients $100 \mathrm{mg}$ tramadol diluted in $10 \mathrm{ml}$ normal saline was also injected epidurally, while $4 \mathrm{mg}$ epidural morphine was used in the other ten patients. In all patients, the visual analogue pain score, $\mathrm{PaO}_{2}, \mathrm{PaCO}_{2}$ and respiratory rate were monitored every hour for the first $24 \mathrm{hr}$ postoperatively. In both the tramadol and morphine groups, the mean hourly pain scores ranged from $0.2 \pm 0.6$ to $1.4 \pm 2.5$ throughout the period of observations. However, the mean $\mathrm{PaO}_{2}$ was decreased postoperatively in the epidural morphine group, while no change was observed in the epidural tramadol group. The maximal decrease of $\mathrm{PaO}_{2}$ in the epidural morphine group was observed at the tenth hour postoperatively, when it decreased to $72.8 \pm 10.3 \mathrm{mmHg}$. This was not associated with any increase in $\mathrm{PaCO}_{2}$ or a decrease of respiratory rate, suggesting that hypoxaemia rather than hypercarbia or decreased respiratory rate may be an earlier indicator of respiratory depression in patients breathing room air without oxygen supplementation. The absence of clinically relevant respiratory depression following epidural tramadol compared with epidural morphine may be attributed to the different mechanisms of their analgesic action. The results suggest that epidural tramadol can be used to provide prolonged postoperative analgesia without serious side effects.

\section{Key words}

ANALGESIA: postoperative;

ANALGESICS: morphine, tramadol; ANAESTHETIC TECHNIQUES: epidural.

From the Departments of Anesthesiology, Surgery and Epidemiology, and Biostatistics, American University of Beirut, Beirut-Lebanon.

Address correspondence to: Anis Baraka, Department of Anesthesiology, American University of Beirut, Beirut Lebanon.

Accepted for publication December 1, 1992.
Anis Baraka MBBCh DA DM MD FRC Anaesth (Hon), Samar Jabbour MD, Maroun Ghabash MD, Antoun Nader MD, Ghattas Khoury MD, Abla Sibai Ms
Cette étude compare le tramadol à la morphine donnée par voie épidurale pour l'analgésie postopératoire de 20 patients subissant une chirurgie abdominale majeure. Les patients sont anesthésiés par une technique balancée, combinée à une épidurale lombaire à la lidocaïne. Chez dix des patients, tramadol $100 \mathrm{mg}$ dilué de $10 \mathrm{ml}$ de liquide physiologique est également injecté par voie épidurale, tandis que morphine épidurale 4 $m g$ est injectée aux autres patients. Chez tous les patients, une échelle visuelle analogue de la douleur, la $\mathrm{PaO}_{2}$, la $\mathrm{PaCO}_{2}$ et la fréquence respiratoire sont mesurées chaque heure pendant les 24 premières heures postopératoires. Autant dans le groupe tramadol que dans le groupe morphine, la valeur moyenne de lévaluation de la douleur se situé de 0,2 $\pm 0,6$ à $1,4 \pm 2,5$ pendant toute la période d'observation. $\mathrm{La} \mathrm{PaO}_{2}$ moyenne est cependant diminuée en postopératoire dans le groupe épidurale à la morphine tandis qu'aucun changement n'est observé dans le groupe épidurale au tramadol. La diminution maximum de la $\mathrm{PaO}_{2}$ dans le groupe épidurale à la morphine se situe à la dixième heure postopératoire, et atteint une valeur de 72,8 $\pm 10,3 \mathrm{mmHg}$. Elle n'est associée à aucune augmentation de $\mathrm{PaCO}_{2}$ ni à une diminution de fréquence respiratoire, suggérant que l'hypoxémie plutôt que l'hypercapnie vu la diminution de fréquence respiratoire peut être un indice précoce de la dépression respiratoire chez des patients respirant l'air ambiant sans supplément d'oxygène. L'absence de dépression respiratoire cliniquement significative après une épidurale au tramadol par rapport à une épidurale à la morphine peut être attribuée à un mécanisme d'action analgésique différent. Ces résultats suggèrent qu'une épidurale au tramadol peut être utilisée pour procurer une analgésie post-opératoire prolongée sans effets secondaires sérieux.

Epidural morphine has been used for postoperative analgesia. However, many side effects such as nausea, vomiting, pruritus, urinary retention, and delayed respiratory depression have been reported. ${ }^{1-6}$ Although rare, delayed resporatory depression is the most serious complication and may occur several hours after the administration of epidural morphine.

One(m-methylphenyl)-2-(dimethylaminoethyl)-cyclohexan-1-01(tramadol; Tramal $\left.{ }^{*}\right)^{7}$ is a new synthetic opioid 
drug and has been advocated as an analgesic without respiratory depression when used parenterally. ${ }^{8,9}$ Recently, tramadol has been reported to depress the spinal nociceptive receptors in the rat, ${ }^{10}$ indicating that, like morphine," it acts at the spinal level. In man, preliminary reports have shown that epidural tramadol can provide postoperative analgesia safely without any serious side effects. ${ }^{12}$

The present study compared epidural tramadol with epidural morphine for postoperative analgesia in patients undergoing major abdominal surgery. The report also compared the incidence of side effects such as itching, nausea and vomiting, as well as the changes of arterial blood gases during the first $24 \mathrm{hr}$ postoperatively.

\section{Methods}

The investigation was approved by the Institution Research Committee, and an informed consent was obtained from all patients.

Twenty patients, ASA physical status II and III, were scheduled for elective major abdominal surgery. The patients were randomly divided into two groups $\mathrm{A}$ and $\mathrm{B}$. Group A consisted of ten patients receiving epidural tramadol, while Group B consisted of ten patients receiving epidural morphine. The type of surgery and the demographic data of the two groups were similar (Table I).

On the evening of the operation, the patients were informed about the purpose of the study, and were introduced to the visual analogue pain scale. ${ }^{12}$ All patients received premedication with $0.4 \mathrm{mg}$ scopolamine im 45 min before surgery. In the operating room, an epidural catheter was inserted, in the lateral decubitus position, at the $\mathrm{L}_{2}-\mathrm{L}_{3}$ or $\mathrm{L}_{3}-\mathrm{L}_{4}$ level. An initial dose of $5 \mathrm{ml} \mathrm{li-}$ docaine $2 \%$ was injected via the epidural catheter, to be followed by an additional $10 \mathrm{ml}$. Patients in Group A also received via the epidural catheter $100 \mathrm{mg}$ tramadol diluted in $10 \mathrm{ml}$ normal saline, while those in Group $B$ received $4 \mathrm{mg}$ morphine in $10 \mathrm{ml}$ normal saline.

A catheter was inserted into the radial artery of all patients. Anaesthesia was induced with thiopentone 5 $\mathrm{mg} \cdot \mathrm{kg}^{-1}$, and tracheal intubation was facilitated with succinylcholine $1.5 \mathrm{mg} \cdot \mathrm{kg}^{-1}$. Anaesthesia was maintained with $\mathrm{N}_{2} \mathrm{O}: \mathrm{O}_{2}(2: 1)$, with vecuronium as a muscle relaxant. No parenteral analgesic drugs were given intraoperatively. Intermittent positive-pressure ventilation was continued throughout the surgical procedure. At the end of the operation, neuromuscular blockade was reversed with a mixture of atropine $\left(0.02 \mathrm{mg} \cdot \mathrm{kg}^{-1}\right)$ and neostigmine $\left(0.05 \mathrm{mg} \cdot \mathrm{kg}^{-1}\right)$, and the trachea was extubated.

All patients were monitored for $24 \mathrm{hr}$ postoperatively in the postoperative care unit. Patients received oxygen by face mask during the first $30-45 \mathrm{~min}$ following surgery, which was followed by spontaneous breathing of room
TABLE I Demographic data and type of surgery in the epidural tramadol and epidural morphine groups

\begin{tabular}{lll}
\hline & $\begin{array}{l}\text { Group A (10) } \\
\text { tramadol }\end{array}$ & $\begin{array}{l}\text { Group B (10) } \\
\text { morphine }\end{array}$ \\
\hline Age (yr) & $59.8 \pm 12.3$ & $58.4 \pm 8.8$ \\
Male/female & $9: 1$ & $6: 4$ \\
Weight (kg) & $62.2 \pm 9.8$ & $70 \pm 12.6$ \\
Surgery time (hr) & $4 \pm 1.0$ & $5 \pm 2.4$ \\
Type of surgery: & & \\
- Repair of infrarenal aortic & & \\
$\quad$ aneurysm & 3 & 3 \\
- Aorto-femoral grafting & 4 & 4 \\
- Radical Cystectomy & 3 & 3 \\
\hline
\end{tabular}

air with no oxygen supplementation. The following variables were assessed by a chief resident who was blind to the epidural narcotic used.

\section{Pain score}

Intensity of postoperative pain during the first $24 \mathrm{hr}$ postoperatively was assessed every hour using the linear analogue pain score..$^{13} 0$ denotes "no pain," while 10 denotes "worst pain imaginable."

\section{Respiration}

The depressant effects of epidural morphine or epidural tramadol on respiration were assessed by monitoring the arterial $\mathrm{PO}_{2}$ and $\mathrm{PCO}_{2}$, as well as the respiratory rate every hour during the first $24 \mathrm{hr}$ postoperatively. The mean hourly values of $\mathrm{PaO}_{2}, \mathrm{PaCO}_{2}$ and respiratory rate were compared in each group with the corresponding control values monitored prior to induction of anaesthesia.

\section{Other side effects}

The incidence of itching, nausea and vomiting during the first $24 \mathrm{hr}$ postoperatively was compared in the two groups. Although urinary retention is a recognized side effect of epidural narcotics, it was not possible to assess its incidence in our patients who had an indwelling bladder catheter during the first $24 \mathrm{hr}$.

All data are presented as mean values $\pm \mathrm{SD}$. Analysis of variance (ANOVA) for repeated measurements using SPSS programme was conducted to compare the hourly pain scores, $\mathrm{PaO}_{2}, \mathrm{PaCO}_{2}$, and respiratory rate values. $P<0.05$ was considered significant.

\section{Results}

\section{Linear analogue pain score}

The mean hourly pain scores in the epidural tramadol and the epidural morphine groups during the first $24 \mathrm{hr}$ postoperatively are shown in Figure 1. Comparison of 


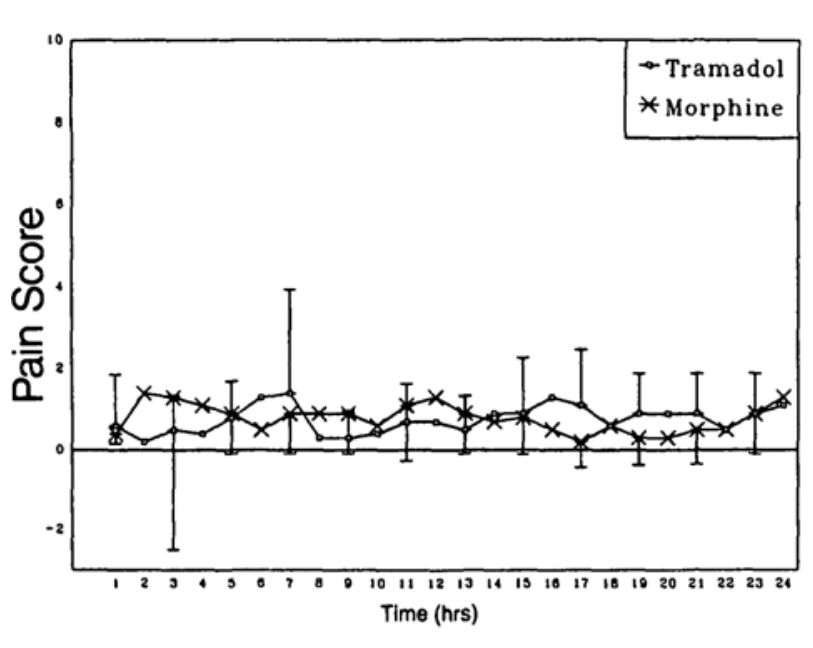

FIGURE 1 The mean pain scores in the epidural tramadol and the epidural morphine groups during the first $24 \mathrm{hr}$ after surgery.

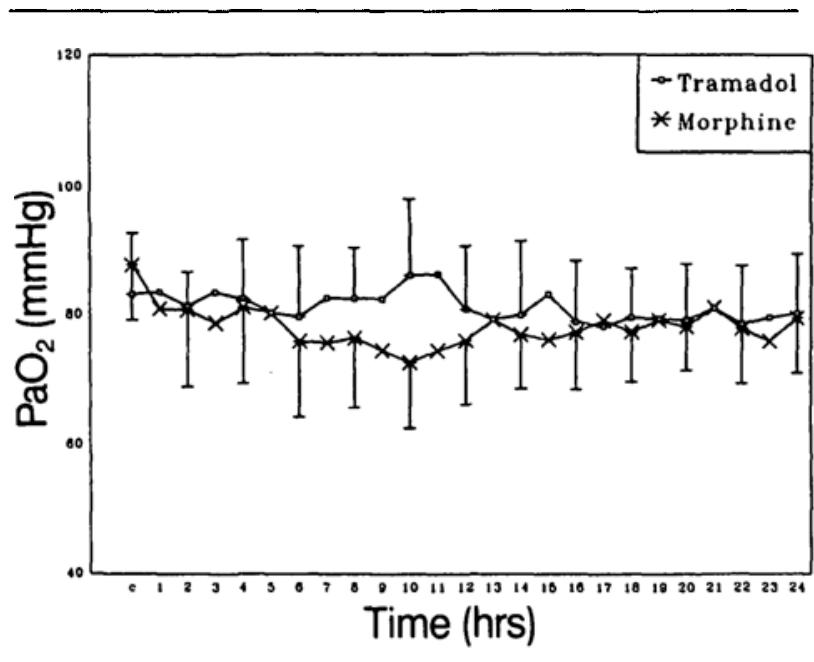

FIGURE 2 The mean $\mathrm{PaO}_{2}$ in the epidural tramadol and the epidural morphine groups during the first $24 \mathrm{hr}$ after surgery.

the hourly pain scores demonstrated good pain relief in both groups with mean pain scores ranging from $0.2 \pm$ 0.6 to $1.4 \pm 2.5$ in both groups (NS).

\section{Arterial blood gases}

During the first $24 \mathrm{hr}$ postoperatively, compared with preoperative control values, the mean $\mathrm{PaO}_{2}$ did not change in the epidural tramadol group, while it decreased in the morphine group from the sixth hour postoperatively. The maximal decease of $\mathrm{PaO}_{2}$ in the morphine group was observed at the tenth hour postoperatively, when the mean $\mathrm{PaO}_{2}$ was $72.8 \pm 10.3 \mathrm{mmHg}$ (Figure 2). The mean hourly $\mathrm{PaCO}_{2}$ values and the mean res-

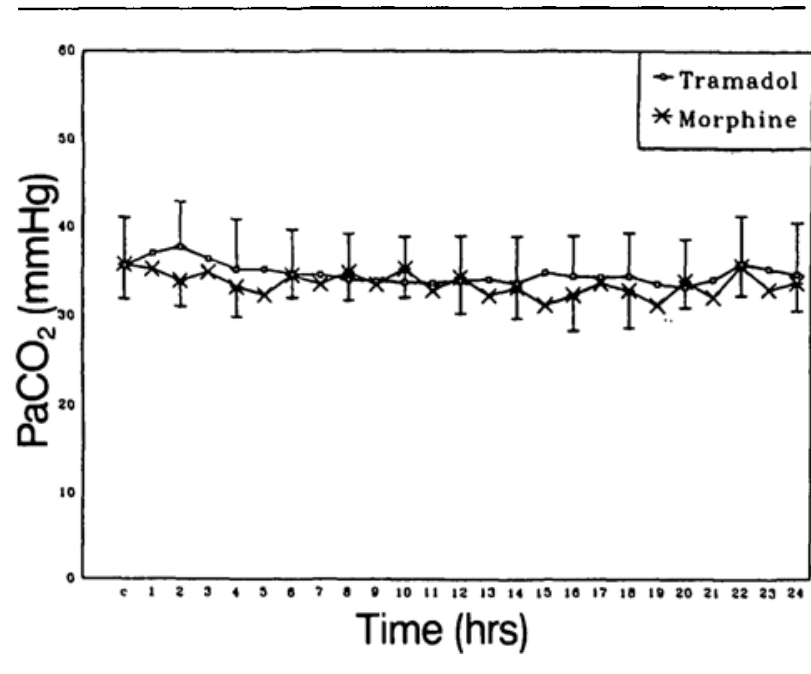

FIGURE 3 The mean $\mathrm{PaCO}_{2}$ in the epidural tramadol and the epidural morphine groups during the first $24 \mathrm{hr}$ after surgery.

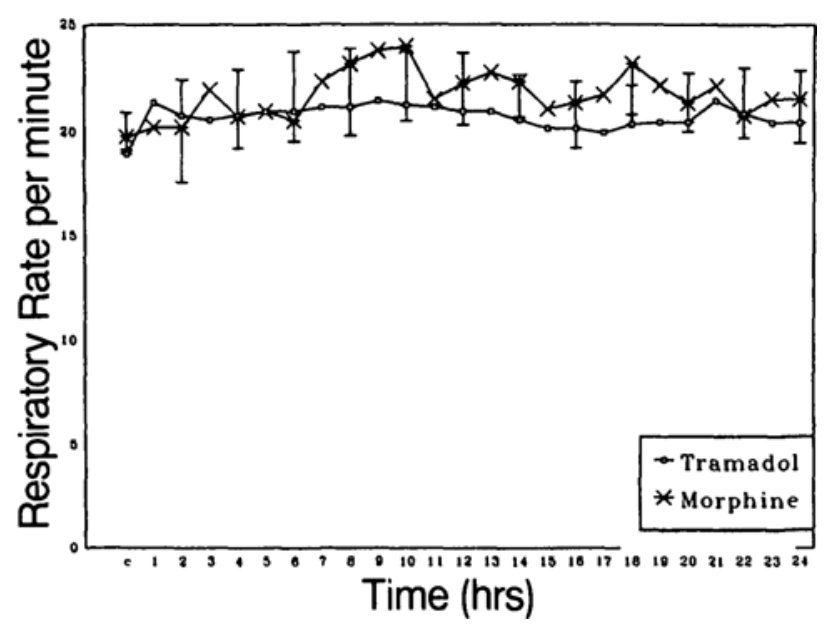

FIGURE 4 The mean respiratory rate per minute in the epidural tramadol and the epidural morphine groups during the first $24 \mathrm{hr}$ after surgery.

piratory rates did not change in either group. (Figures 3 and 4).

\section{Side effects}

One patient in the tramadol group had itching versus two patients in the morphine group. Two patients in the tramadol group had nausea and vomiting versus four patients in the morphine group. No differences were noted between the two groups (Table II).

\section{Discussion}

The present report shows that epidural tramadol, like morphine, can provide adequate and prolonged postoperative 
TABLE II Side effects during the first $24 \mathrm{hr}$ after surgery in the epidural tramadol and the epidural morphine groups

\begin{tabular}{lll}
\hline & $\begin{array}{l}\text { Group } A(10) \\
\text { tramadol }\end{array}$ & $\begin{array}{l}\text { Group B (10) } \\
\text { morphine }\end{array}$ \\
\hline Itching & 1 & 2 \\
Nausea/vomiting & 2 & 4 \\
\hline
\end{tabular}

analgesia in patients undergoing major abdominal surgery. Also, the incidence of itching, nausea and vomiting was similar in the two groups. However, epidural tramadol, despite the relatively high dose used, was not followed by delayed respiratory depression. Patients in this group showed no changes of $\mathrm{PaO}_{2}$ or $\mathrm{PaCO}_{2}$ during the first $24 \mathrm{hr}$ postoperatively whereas, in the epidural morphine group, the $\mathrm{PaO}_{2}$ was decreased from the sixth hour postoperatively, but without decrease of respiratory rate or increase of $\mathrm{PaCO}_{2}$. The maximal decrease of mean $\mathrm{PaO}_{2}$ in the morphine group was observed at the tenth hour postoperatively, when the $\mathrm{PaO}_{2}$ was $72.8 \pm$ $10.3 \mathrm{mmHg}$.

Many studies of epidural morphine have failed to detect clinically important respiratory depression.' Altered chemosensitivity, in particular depression of the $\mathrm{CO}_{2}$ response curve, is considered a sensitive index of respiratory depression. However, calculation of the $\mathrm{CO}_{2}$ response curve is time-consuming and requires patient cooperation. Also, it has not been determined whether an altered $\mathrm{CO}_{2}$ response curve is a reliable prediction of transient apnoea or hypoventilation. ${ }^{1}$ Monitoring respiratory rate is the simplest form of monitoring. However, as shown by the present and previous reports, patients may be hypoxaemic and/or hypercarbic, yet have a normal respiratory rate. ${ }^{6}$ Also, $\mathrm{PaCO}_{2}$ has been considered the essential index of alveolar ventilation. However, the body oxygen stores are limited compared with the very large carbon dioxide stores. Therefore, acute alveolar hypoventilation can rapidly decrease the arterial $\mathrm{PO}_{2}$, while the $\mathrm{PaCO}_{2}$ may still be within the normal range. ${ }^{14}$ This may cause an erroneous diagnosis of shunting rather than hypoventilation. ${ }^{13}$ Also, hypoxaemia may trigger the hypoxic drive via the peripheral chemoreceptors, ${ }^{15}$ and can partially counteract the decrease of respiratory rate and/or tidal volume. The limited body oxygen stores as well as activation of the hypoxic drive may explain our findings which suggest that hypoxaemia rather than elevation of $\mathrm{PaCO}_{2}$ or a decrease of respiratory rate may be an early signal of respiratory depression following epidural morphine in patients breathing room air without oxygen supplementation. On the other hand, breathing oxygen causes a substantial increase in the alveolar oxygen concentration, and hence respiratory depression can manifest by an increased $\mathrm{PaCO}_{2}$, without compromising the $\mathrm{PaO}_{2}{ }^{14}$

Pulse oximetry may be useful as a simple noninvasive technique for continuous and long-term monitoring of oxygenation during the postoperative period in patients receiving epidural narcotics. In the presence of supplemental oxygen, however, saturation may be well maintained despite hypoventilation or apnoeic episodes.'

The immediate postoperative period is a potentially high risk time for the occurence of hypoxaemia. ${ }^{16}$ The pathogenesis of postoperative hypoxaemia is multifactorial. ${ }^{17}$ Hypoxaemia in the early postoperative period is likely to be caused partly by the reduction in functional residual capacity (FRC) secondary to anaesthesia and surgery. ${ }^{18}$ The reduction of FRC and the consequent alteration in the relationship of closing volume to $\mathrm{FRC}^{19}$ can result in ventilation-perfusion mismatching. Following upper abdominal surgery, diaphragmatic function is also impaired and additional splinting by abdominal distension and pain may promote pulmonary atelectasis. ${ }^{20}$ The respiratory depressant effects of opioid analgesia also have an important role in the production of postoperative hypoxaemia. ${ }^{17}$

Previous clinical reports have also shown that parenteral morphine results in greater, and clinically important, respiratory depression than equi-analgesic doses of parenteral tramadol. 8,9 The absence of respiratory depression following epidural or parenteral tramadol compared with epidural or parenteral morphine may be attributed to the different mechanisms of their analgesic actions.

Morphine acts selectively as an opiate agonist, which can produce analgesia as well as respiratory depression. Morphine is a mu and kappa agonist. ${ }^{21} \mathrm{Mu}$ receptors mediate analgesia and respiratory depression, while kappa receptors mediate analgesia and sedation. Whether kappa agonist activity contributes to respiratory depression is uncertain. Also, because of the highly ionized and hydrophilic nature of morphine, egress of the drug transferred to the spinal fluid following its epidural administration will be slow, resulting in a high CSF concentration of morphine available to move cephalad to reach supra-spinal structures and produce delayed respiratory depression, ${ }^{2}$ probably by its action on the central chemoreceptors which lie very superficially, $0.2 \mathrm{~mm}$, beneath the antero-lateral surface of the medulla, bathed in the CSF ${ }^{1,15}$

In contrast with morphine which acts selectively as an opiate agonist, the analgesic effects of tramadol are mediated by an opioid, ${ }^{22}$ as well as a non-opioid receptor mechanism of action. ${ }^{22,23}$ Tramadol is a weak agonist at all types of opioid receptors with some selectivity for mureceptors. ${ }^{22}$ More recent work, however, suggests that non-opioid receptors mechanisms of action may contrib- 
ute to the analgesic profile. Tramadol inhibits noradrenaline uptake and stimulates serotinin release; and these are transmitters in the descending pathways which enhance analgesia. ${ }^{23,24}$ The non-opioid mechanisms may potentiate the analgesia of epidural tramadol, without inducing respiratory depression. Previous reports have shown that the combination of an opioid and non-opioid such as an $\alpha_{2}$-adrenergic agonist may act synergistically for the analgesic response without potentiating respiratory depression. 25,26

Finally, it is interesting to note that a single dose of epidural morphine or epidural tramadol as the sole analgesic agent could provide in our population such prolonged and low pain scores during the first $24 \mathrm{hr}$ after surgery. This observation confirms our previous study which showed that the requirement for postoperative analgesics was lower in patients operated upon during and after the Lebanese war than in those patients operated upon before the war. ${ }^{27}$ Also, elderly patients may requires less narcotics than young patients. ${ }^{28}$

In conclusion, our report shows that epidural tramadol can provide adequate and prolonged postoperative analgesia, without early or delayed clinical respiratory depression. In contrast, epidural morphine may be followed by delayed respiratory depression as evidenced by the decrease of $\mathrm{PaO}_{2}$; the maximal decrease of $\mathrm{PaO}_{2}$ was observed at the tenth hour postoperatively. This report suggests that in patients breathing room air without oxygen supplementation, a decrease of $\mathrm{PaO}_{2}$ rather than an increase of $\mathrm{PaCO}_{2}$ or a decrease in respiratory rate may be an early indicator of respiratory depression following epidural morphine. The absence of respiratory depression following epidural tramadol compared with morphine may be attributed to their different mechanisms of action.

\section{References}

1 Etches $R C$, Sandler $A N$, Daley $M D$. Respiratory depression and spinal opioids. Can J Anaesth 1989; 36: 165-85.

2 Cousins MJ, Mather LE. Intrathecal and epidural administration of opioids. Anesthesiology 1984; 61: 276-310.

3 Knill RL, Clement JL, Thompson WR. Epidural morphine causes delayed and prolonged ventilatory depression. Can Anaesth Soc J 1981; 28: 537-43.

4 Bromage $P R$. The price of intraspinal narcotic analgesia: basic constraints (Editorial). Anesth Analg 1981; 60: 461-3.

5 Morgan $M$. Quidquid agas, prudenter agas, et respice finem: whatever you do, do cautiously, and look to the end (Editorial). Anaesthesia 1982; 37: 527-9.

6 Rawal N, Wattwil M. Respiratory depression after epidural morphine - an experimental and clinical study. Anesth Analg 1984; 63: 8-14.

7 Friderichs E, Felgenhauer F, Jongschaap P, Osterloh G. Pharmalogische Untersuchungen von tramadol, einem stark wirkenden Analgetikum. Arzneimittel-Forschung 1978; 28: 122-34.

8 Houmes $R-J M$, Voets $M A$, Verkaaik A, Erdmann $W$, Lachmann $B$. Efficacy and safety of tramadol versus morphine for moderate and severe postoperative pain with special regard to respiratory depression. Anesth Analg 1992; 75: 510-4.

9 Vickers MD, O'Flaherty D, Szekely SM, Read M, Yoshzumi J. Tramadol: pain relief by an opioid without depression of respiration. Anaesthesia 1992; 47: 291-6.

10 Carlsson $K-H$, Jurna I. Effects of tramadol on motor and sensory responses of the spinal nociceptive system in the rat. Eur J Pharmacol 1987; 139: 1-10.

11 Yaksh $T L$, Rudy TA. Analgesia mediated by a direct spinal action of narcotics. Science 1976; 192: 1357-8.

12 Chrubasik J, Warth L, Wust H, Zindler M. Analgesic potency of epidural tramadol after abdominal surgery. Pain (1987) Suppl 4, Abstract No 296. 5th World Congress on Pain, Hamburg, 1987.

13 Revill SI, Robinson JO, Rosen M, Hogg MIJ. The reliability of a linear analogue for evaluating pain. Anaesthesia 1976; 31: 1191-8.

14 Nunn JF. Ventilatory failure. In: Nunn JF (Ed.). Applied Respiratory Physiology, 3rd ed., London: Butterworths, 1987; 379-91.

15 Duffin J. The chemoreflex control of breathing and its measurement. Can J Anaesth 1990; 37: 933-42.

16 Daley $M D$, Norman PH, Colmenares ME, Sandler AN. Hypoxaemia in adults in the post-anaesthesia care unit. Can J Anaesth 1991; 38: 740-6.

17 Reeder MK, Goldman MD, Loh L, et al. Postoperative hypoxaemia after major abdominal vascular surgery. $\mathrm{Br} \mathbf{J}$ Anaesth 1992; 68: 23-6.

18 Hedenstierna $G$. Gas exchange during anaesthesia. $\mathrm{Br} \mathrm{J}$ Anaesth 1990; 64: 507-14.

19 Alexander JI, Spence AA, Parikh RK, Stuart B. The role of airway closure in postoperative hypoxaemia. $\mathrm{Br} \mathrm{J}$ Anaesth 1973; 45: 34-40.

20 Ford GT, Whitelaw WA, Rosenal TW, Cruse PJ, Guenter $C A$. Diaphragm function after upper abdominal surgery in humans. Am Rev Respir Dis 1983; 127: 431-6.

21 Yaksh $T L$, Noueihed $R$. The physiology and pharmacology of spinal opiates. Annu Rev Pharmacol Toxicol 1985; 25: 433-62.

22 Hennies $H H$, Fridericks E, Schneider J. Receptor binding, analgesic and antitussive potency of tramadol and other selected opioids. Arzneimittel-forschung 1988; 38: 877-80.

23 Dhasmana KM, Banerjee AK, Rating W, Erdmann W. Analgesic effect of tramadol in the rat. Chung Kuo Yao Li Hsueh Pao 1989; 10: 289-93.

24 Kayser V, Besson J, Guilbaud G. Effects of the analgesic agent tramadol in normal and arthritic rats: comparison with the effects of different opioids, including tolerance and 
cross-tolerance to morphine. Eur J Pharmacol 1991; 195 : 37-45.

25 Bailey PL, Sperry RJ, Johnson GK, et al. Respiratory effects of clonidine alone and combined with morphine in humans. Anesthesiology 1991; 74: 43-8.

26 Jarvis $D A$, Duncan $S R$, Segal IS, Maze $M$. Ventilatory effects of clonidine alone and in the presence of alfentanil, in human volunteers. Anesthesiology 1992; 76: 899-905.

27 Armenian $H K$, Chamieh MA, Baraka A. Influence of wartime stress and psychosocial factors in Lebanon on analgesic requirements for postoperative pain. Soc Sci Med 1981; 15E: 63-6.

28 Scott JC. Stanski DR. Decreased fentanyl and alfentanil dose requirements with age. A simultaneous pharmaconetic and pharmacodynamic evaluation. J Pharmacol Exp Ther 1987; 240: 159-66. 